\title{
Modern Educational Technologies and National Interests
}

\author{
Emin Garibli ${ }^{1 *}$, Aysel Garibli ${ }^{2 *}$ \\ $1 *$ Assoc. Prof.Dr., Azerbaijan State University of Economics, Faculty of Economics, International Economics \\ Department- Email: egaribli@ hotmail.com \\ 2* Assoc. Prof. Dr. Leading researcher in Azerbaijan National Academy of Science \\ (Institute of Linguistics named after Nasimi)- email: aysel-qerib@hotmail.com
}

Article History: Received: 10 November 2020; Revised 12 January 2021; Accepted: 27 January 2021; Published online: 5 April 2021

\begin{abstract}
As we know, one of the lifelong learning forms, which is the correspondence education, has received a wide circulation in our country. However, we have recently mentioned that the type of education should be adapted to modern conditions. As a way out from this situation, the article analyzed the specifics of the distance and supplementary education in the world and the stages of development. Mechanisms of application of existing educational technologies in Azerbaijan were studied. In order to achieve the goals mentioned in the article, the relevant legislation of Azerbaijan has been prepared and recommendations for institutional reforms have been prepared. In the context of globalization, the development of new technologies has negative effects, though there are positive effects. The strengthening of globalization leads to the inequality of development among countries, the sharp differences in the living standards of the population, the escalation of language, religion, traditions and, ultimately, the weakening of national state institutions. In this case, the protection and development of the state language is of great importance and special attention should be paid to this problem. At the end of the article, we came to the problem from another aspect, and we believe that if we use the right technologies properly and precisely, it can be achieved through the promotion of mother tongue. Our compatriots living abroad will be able to acquire new knowledge and will not forget and develop their mother tongue with effective use of remote training technologies. Millions of our compatriots living abroad will be able to benefit from these advantages. In order to achieve this, it is important to use the modern IT technologies' innovations as well as the effective use of language teaching methods for language development carried out by linguists.

We believe that there is a relationship between these two factors, and when analyzing lifelong learning issues, there is a need for two aspects. At the end, it should be noted that we have to analyze the problem from different perspectives and make suggestions.
\end{abstract}

Keywords: Distance education, Part-time education, Open University, Legislation, Development Concept, Turkish language.

\section{Introduction}

The deepening of globalization processes and the integration of countries can take up from three to five years. Information systems of the education system and meeting modern requirements are considered as one of the most important priorities of all states and international organizations. In this regard, it is considered appropriate to consider the traditions of contemporary education in the world. The development of the distance education 
system that meets the requirements of the globalization process in the world is one of the most important aspects of the development concepts of the states and education policy. At least 4 new technologies are needed to adopt each new generation's labor activity. For this reason, experimental and theoretical knowledge needs constant renewal.

World experience shows that people tend to continually improve, lifelong learning continuously (Lifelong Learning). Due to the introduction of new technologies in the oftenchanging world, there is a need for continuous education to adapt to these socio-economic conditions.

Increasing the quality of part-time education in the country is one of the most urgent issues and it has been talked about regularly. It is known that time spent in part-time education is very limited. Even in many cases, every working student can not find time for lessons. In the 2017-2018 academic year, the number of students in the bachelor's degree in Azerbaijan was 12,606. At the Azerbaijan State Economic University, the number of part- time students in the 2018-2019 academic year were 2115 people. Obviously, the number of part-time students studying in our country is quite enough. From this perspective, the application of distance learning can help solve these problems. The highest number of students in the correspondence department is the Azerbaijan State Economic University, Baku State University, and the Azerbaijan State Pedagogical University (2019).

Employees apply for this kind of education to get education without leaving work. The negative side of this type of education can be summarized as follows:

1) The role of teachers in the part-time education and limited communication with them.

2) lack of academic hours.

3) limited scientific literature and so on.

These types of disadvantages in part-time education can be solved by providing up-todate training to distance learning. These days, education is a great business area in the world. Distant education is an important tool and technology of education in the international education market. Although distant education is profitable, such universities are owned and operated by the state. Distinguished by the fact that the educational form of the 21 st century is the most promising, some experts have characterized this type of education as a political atmosphere.

The informatization of education system is one of the most important priorities of all states and international organizations. Therefore, it is expedient to take into consideration the modern educational traditions gained credibility in the world. The development of distant education system which meets the requirements of global processes taking place in the world is one of the important directions of the development conceptions and educational policy of states.

The development of distant education is the main direction of educational programs and it is defined as the priority in the item 126 of the Maastricht Treaty of the European Union. This direction is an important part of state policy in large states and international agencies, including our Republic. Therefore, it's possible to note the following Statutes and Decrees of the President of the Azerbaijan Republic (Garibli E.A. 2015):

1) A State Program on reforms in the higher education system of the Azerbaijan Republic in 2009-2013s; 
2) "Azerbaijan 2020: Looking into the Future" Development Concept which had been submitted by the Decree dated December 29, 2012 of the President of the Azerbaijan Republic;

3) Action Plans of declaring 2013as "The Year of Information and Communication Technologies" in the Azerbaijan Republic.

In our opinion, the preparation of the theoretical - methodological bases and the investigation of development trends of distant education are very significant.

There is no common definition of distant education in the world today. The terms, such as "Distance Education", "Learning" and "Distance Learning" are mainly used in English speaking countries. The term Distant Education is mainly widespread in the countries of CIS. The word Learning means "to learn", i.e. to study independently in the Azerbaijan language. It expresses the meaning to study independently via either internet or various technical means "Distant Learning" and "Learning" are accepted as the forms of Distant Education for English-speaking authors. We want to take into your consideration that in the usage of the expression "open and distant learning" the word learning is used. Here we mean to learn without teachers and independently. The meaning of Distant Education is to learn and to master higher education programs while making use of modern equipment's. We should note that teachers help to students to master specialists and professions in modern conditions. Therefore, Distant Education system is adult education and is a component of "Distant Learning" and "Distant Education".

According to some specialists, "Distant Learning" is the preparation of certain short-term training courses. So, education is translated as - training, learning, reading and so on in some dictionaries. A Russian word «обучение» is accepted as to study in the form of distant education.

The basic principles of distant education: In Distant Education, everyone can read at universities without losing time. Here, the student has the principle of free learning. The education is structured so that it can be separated from the teacher by time or distance, and they can communicate with the trainee, the teacher, and the telecommunications equipment at any time. Distant education in any area of education is possible. In Distant Education, teacher assignments, tests, and supplementary materials are sent to the student, and the student will perform all the tests and studies and send them to the teacher. Classes continue this principle by the end of the semester.

Distant Education, which is widely used all over the world, is still not widely spread in our country. The reason for this is that people do not have education in this field, the lack of appropriate technical basis and jobs that meet the market conditions.

In general, distant education has many advantages:

- So many parents do not risk sending their children away from them, or the family's financial ability to study abroad is insufficient.

- The ability to read and work

- Compared to visual education, it is a suitable payment

- Free education system

- Chance to pay with your credit card system 
- Classes do not suit their own capabilities

Today education and its quality are very important. In fact, many young people in the country are unable to benefit from the right to education because of personal problems. Distant education system has advantages in this regard. At a time when technology is rapidly developing, distant education is also accessible and there is a necessity. This form of education can also be support for formal education. Distant education is a new form of education for Azerbaijan. Experts believe that to implement distant education in the country, first of all, it is necessary to apply the world experience. In many foreign countries, there are special universities operating in such educational systems.

There is a large history of this kind of education. About 1728, the concept of distant education has remained unchanged, but communication has changed. At that time, Kaleb Filips was the first organizer of distance learning, announcing "accounting and short-term correspondence courses" in Boston. The development of regular postal service has created a fertile ground for distant education (Mayoka, 2014). Thus, this communication, non-service remote communication connections was unstable and slow. The Philippines ad is in the following form:

"Knowledge levels of citizens who want to get these occupations will be the same as the level of students in Boston after receiving a few lessons".

The new stage of distant education has been linked to the active movement of the English language towards democratization in the world. In 1840-1890, Sir Isaac Pitman mailed the letter of delivery to the postal delivery price, that is, writing letters for short periods without profit. According to Sir Pitman, democratization of society depends on the ability of people to obtain higher education regardless of their political convictions or their social status (Fetisova A.D. 2015).

Based on the experience of the International Correspondence School in 1890, the reason for the establishment of a distant education school in 1880 was to provide career demands for miner's immigrants. They wanted to be a brigade to avoid frost, but education was required.

About a million students have been registered for eighteen years because of powerful advertising. This was a great indicator for the industry and the country, given that the US population at that time was 75 million, but the results were unexpected. Thus, $83.4 \%$ of the students failed to pass through $1 / 3$ of the course and only $2.3 \%$ were awarded the title of graduate. One of the ICS's managers wrote that they were freed from classes because they did not have self-motivation and practical knowledge. One hundred years ago, it became clear that distant education was self-educational, and knowledge gained by individuals with a high culture. Radio and Television Education was the first prototype of "divested universities." New communications have led to new experiences in distant education. The development of the radio has led to the fact that students could sit at home and listen to lectures like in the university building. Clearly, issues and lectures are still being sent through paper, but radio broadcasts communication between student and teacher. The Pennsylvania State University was the first to broadcast its training on radio in 1922. But in 1934, the first television channel of the University of Iowa began to work. By the way, let's note that the channel continues to operate till today (Gromova 2011). 
During the rapid development of technology, in the early 1970s, again, the universe of ideal higher education ideologies fired. In the US in the mid-1960s, new methods of distant learning emerged. The University of Experiments (UECU) sponsored by prestigious sponsors at Universities and Colleges that have implemented new techniques. In 1970, well-known universities were included in the community (Sharova, 2015). For those years, the concept of Community Revolution (University without the University Building, abbr UWW) has been published in today's criteria:

1. There were no age restrictions for admission;

2. Students should be involved in the creation and improvement of the curriculum;

3. Maximize the self-study;

4. Adapt curriculum to course of study according to individual circumstances and needs of students;

5. It is important to involve experienced teachers in these or other areas;

6. Free access to UWW network in-house training materials;

7. Determination of new methods of assessment because of the lack of objectivity of the old evaluation methods (tests, attendance in lectures).

As you can see, this project can be regarded as a university, but a few universities have attempted to develop distant education and training programs. Unfortunately, during the twelve-academic year, only a thousand students were able to earn a Bachelor's degree. However, there are many positive aspects of this project, since the age limit was removed from the universities and the opportunity to study at the age of 30 became the reason for the number of higher education graduates.

The British Open University, founded in 1969, has revolutionized innovation in distant education. "Open" means unrestricted access to education. Without regard to the level of knowledge, they were admitted to the university without the certificate of secondary education, but those who desired to read. Another indicator of openness was the distance from teaching, ie from countries, without leaving work. Most importantly, because the university is a state-owned, graduates receive a diploma (accredited) (Zaitseva E.A. 2015).

In 1967, the British Minister of Education and Science instructed the University to prepare its work plan and charter. Firstly, it was necessary to study the demand and then to define functions and goals. The number of students from different classes is predicted.

The university was admitted to the age of 21 by the year 1986. Open University was called the second chance university. Designed for 18-year-olds. There is no need to take any exams for admission to the university, and there is no need to certify that a secondary school is to be rescued. The focus of the university was that it was a high-quality training material for intensifying short-term teaching. Open University is a supreme governing body. Students, representatives of the Ministry of Science and Education, the BBC and the royal community are elected members of the council. The members of the Board are elected six times a year, solve the issues of personnel and financial issues. The Jones International University, established in the US in 1999, was the first state-accredited distant university. In addition, the university was established based on television courses broadcast by 30 advanced universities. 
The extensive education in the former Soviet Union is regarded as a form of distant education. For example, academician Kruglov believes that "distant education is similar to education in correspondence." (Kuzminykh, 2015)

The form of correspondence education of the USSR is the first long-distant education prepared by the state. This experience has been used in the former socialist camp and has played a major role in training millions of specialists.

Distant education - correspondence education in the former USSR began to be formed in the 20s of the last century. In the 1926-1927 years, at the faculty of correspondence of Moscow State University, about 37,000 students were trained. At the beginning of the 1930s, correspondence education was widely used in all the leading universities of the USSR. The government was trying to raise the professional level of the workers and peasants. Students first came to the university to get acquainted with the course, after which they took textbooks and closely interacted with teachers to master them. At the end of the year, they returned to the university and exams.

Experience in the USSR shows that only educated and stubborn students were gaining prestige in teaching. Such deficiencies can be solved by providing modern equipment's by converting the correspondence education into distant education. The experience of developing countries, for example Turkey, Israel, India, Thailand, is of great interest to us. Thus, in Israel and Thailand there is a public open university (distant education). Universities offer undergraduate and graduate degrees.

The reason for the great success of higher education institutions in distant education should be sought in its paid education. For example, the budget of the Anatolia University of Turkey today is $\$ 1$ billion. close to USD. Although this university is a state university, it does not receive funds from the state. 400-500 thousand Turks living outside Turkey are studying there, and if they pay 1200-1500 euros, this year $600 \mathrm{mln}$. is equal to euro. Anadolu University's revenues in this area are aimed at the comprehensive development of education in the country. The University freely funded textbooks for first graders. In general, distant education universities have a very rich budget that can be considered a kind of support for the country's economy ( Ni, A. Y. 2015).

Nowadays, education in the world is a great business area. Distant education is an important tool and technology of education in the international education market. Experts believe that by $2015,80 \%$ of world universities will be educated on this technology. Although distant education is profitable, such universities are owned and operated by the state. Since the 21 st century is the most promising educational form in the world, some experts also describe Distant Education as a political tool (UNESCO 2002) .

According to some studies, the drop in demand for formal courses has dropped since the last crisis in the world economy, but demand for Distant Education has increased. This is largely explained by the fact that the right to education in Distant Education is low but consider that the demand for Distant Education is growing steadily over recent years. Thus, according to IDC's research, 1/3 of the European education market is based on Distant Education. In Turkey, 50\% of the students are studying through Distant Education. 13-14\% of students across the world study at distant Gandhi University in India. Corton Consulting estimates that the turnover of distant education will reach 50 billion by the end of this decade. 
However, according to the estimates of the United States National Institute of Standards and Technology, the US has already reached that amount ( Tuckett, 2017)

(According to study by Ambient Insight, the growth rate of distant education in the CIS countries is more than $20 \%$. This indicator is the record for the world.

\section{Method}

Method of the research: analysis and synthesis, comparative, deduction, and induction.

\section{Findings}

Application and development of distant education can help to solve the following problems:

-The development of distant education enables people from all over the country to get education, generally increasing the number and quality of people with higher education among the population and opens an opportunity to rise to the level of developed countries (Israel, India);

- After the launch of Azerbaijan's communication satellite into orbit, the quality of the Internet and communication system will increase. Therefore, Azerbaijanis who live abroad (in Russia, Georgia, Southern Azerbaijan, etc.), using the advantages, allows them to grow their education and profession without coming here;

- Structurally increases the country's industry power by addressing the problem of unemployment (by focusing on the necessary professions);

- Increasing the quality of part-time education to the level of full-time education;

- Can play an exceptional role in establishing a sustainable information society;

- It leads to the integration of Azerbaijani education and science into world science and education.

- Proper, efficient use of distance learning technologies will serve the development of our compatriots living abroad, at the same time not forgetting their mother tongue by getting new knowledge.

\section{Results, Conclusions and Recommendations}

The following results can be concluded from the distant learning form:

1. Open and distance education, eLearning, distance learning, distance education, and parttime education - these are synonyms and forms of distant education.

2. There is a need to make appropriate shift to the legislation for the development of distant education.

The Distant Learning Experience of most countries points that government-driven management (UK, US, Israel, India, Philippines, etc.) is commercially viable.

3. In order to provide distant education, all universities are unwilling to acquire the appropriate material base. So, the experience of the United States shows that several universities may unite and use telecommunication equipments.

4. We consider necessary to organize the state's open distance learning university.

It was the result of investigation for the development of distance education in our country, first and foremost, you need to make changes to the legislation. So the legislation requires a license for the application of distance education, but no licensing procedures have been 
established. We believe that on the basis of international experience it is necessary to prepare relevant rules in a short time.

\section{References}

[1] The State Statistical Committee of Azrbaijan. Education, science and culture(2019) https://www.stat.gov.az/menu/7/

[2] Garibli E.A. (2015) Apple Materials of modern knowledge economy "Scientific news of Azerbaijan State University", 3rd volume, January-March 2015 pp. 80-87.

[3] Mayoka K. G. (2014)How can e-learning integration be realized? An exploratory study in higher education institutions. Asian Journal of Computer Science and Information Technology. No. 5, Vol. 4, p. 164-169.

[4] Fetisova A.D. Distance learning as one of the most important tools in the field of education. Innovative development - from Schumpeter to the present day: economics and education // Articles and reports of the participants of the international scientific-practical conference. $\mathrm{M}:$ : publishing house "scientific consultant", 2015. C.548

[5] Gromova TV (2011) Theory and technology of training university teachers to work in the distance learning system: Author's abstract. diss. ... doct. ped. sciences. - Samara, 2011 [Electronic resource]. - Access mode: http: // http://nauka-pedagogika.com

[6] Sharova S. V. (2015) Trends in the development of Russian business education. Innovative development - from Schumpeter to the present day: economics and education // Articles and reports of the participants of the international scientific-practical conference. $\mathrm{M}$.: publishing house "scientific consultant" 2015. P.546-549

[7] Zaitseva E.A. (2015) Education system in the USA: structure and features // Theoretical \& applied science. 2015. No. 04 (24) S. 218-220

[8] Kuzminykh Zh.O. (2015) Modern trends in the internationalization of higher education in Europe and the USA // Modern problems of science and education. 2015. No. 3. S.524-527

[9] Ni, A. Y. (2015). Comparing the effectiveness of classroom and online learning: Teaching research methods. Journal of Public Affairs Education, 19(2), 199-215.

[10] Open and distance learning. Trends, policy and strategy considerations. Division of Higher Education, UNESCO 2002, 95 p., p. 65-70. rfgovernmentdeci-sions/archive/2008/1 1/17/2982752.htm.

[11] Tuckett, A. The rise and fall of life-wide learning for adults in England. Int. J. Lifelong Educ. 2017, 36, 230-249. 